University of Nebraska - Lincoln

DigitalCommons@University of Nebraska - Lincoln

$11-2011$

\title{
Increasing Higher Level Language Skills to Improve Reading Comprehension
}

\author{
Tiffany Hogan \\ University of Nebraska - Lincoln, thogan2@unl.edu \\ Mindy Sittner Bridges \\ University of Kansas, msittner@ku.edu \\ Laura M. Justice \\ Ohio State University, justice.57@osu.edu \\ Kate Cain \\ Lancaster University, k.cain@lancaster.ac.uk
}

Follow this and additional works at: https://digitalcommons.unl.edu/specedfacpub

Hogan, Tiffany; Bridges, Mindy Sittner; Justice, Laura M.; and Cain, Kate, "Increasing Higher Level Language Skills to Improve Reading Comprehension" (2011). Special Education and Communication Disorders Faculty Publications. 79.

https://digitalcommons.unl.edu/specedfacpub/79

This Article is brought to you for free and open access by the Department of Special Education and Communication Disorders at DigitalCommons@University of Nebraska - Lincoln. It has been accepted for inclusion in Special Education and Communication Disorders Faculty Publications by an authorized administrator of DigitalCommons@University of Nebraska - Lincoln. 


\title{
Increasing Higher Level Language Skills to Improve Reading Comprehension
}

\author{
Tiffany F. Hogan, Mindy Sittner Bridges, Laura M. Justice, and Kale Cain
}

$\mathrm{R}$ eading comprehension involves two primary processes: (a) decoding printed text and (b) understanding language accessed through the process of decoding. In the early years of reading development, children's ability to comprehend text is largely constrained by individual differences in decoding printed text; however, once decoding becomes automatized, reading comprehension is largely dependent upon one's skills in language comprehension (Catts, Hogan, \& Adlof, 2005). In recent decades, numerous studies have investigated how children develop decoding skills and how, when these skills do not develop normally, educators can effectively intervene (e.g., Denton \& Mathes, 2003; Simmons et al., 2008; Vellutino, Scanlon, Small, \& Fanuele, 2006).

Beyond decoding, the substantial role that language skills play in the achievement of skilled reading comprehension has largely been ignored. This is surprising, given that skilled reading comprehension is critical for modern life; success in education, productivity in society, and almost all types of employment require rapid and thorough assimilation of information from text. Further, there are children who develop good decoding skills but fail to develop comparable levels of reading comprehension. A profile of good word reading in the presence of poor comprehension affects approximately $10 \%$ of school-age children (Nation, 2005; Yuill \& Oakhill, 1991) and demonstrates that skills other than decoding are important for successful comprehension.

Clearly a focus on the skills that support text comprehension is essential within the teaching of reading (and communication skills more broadly). In this paper, we provide an overview of a large empirical evidence base that shows that the language skills of inferencing, comprehension monitoring, and use of text structure knowledge are critical to successful comprehension. Because these language skills are not reliant on word reading abilities, we chose to focus on how to stimulate them through shared book readings in early childhood.

\footnotetext{
Dr. Hogan is an assistant professor in the Department of .Special Education and Communication Disorders at the University of Nebraska-Lincoln and an adjunct assistant professor at the Neurogenetic Communication Disorders Consortium at the University of Nebraska Medical Center. Dr. Bridges is a research associate in the Department of Speech-Language-Hearing: Sciences and Disorders at the University of Kansas. Dr. Justice is a professor in the School of Teaching and Learning at Ohio State University. Dr. Cain is a lecturer in the Department of Psychology at Lancaster University.
} 


\section{The Simple View of Reading}

The distinction we make between decoding and comprehension is explained by the Simple View of Reading (Gough \& Tunmer, 1986). The Simple View proposes that reading comprehension is the product of decoding printed text (i.e., word reading) and understanding language accessed through the process of decoding (i.e., listening comprehension). Put simply, children comprehend when they are able to accurately and fluently translate print into spoken language that they can understand. Figure 1 illustrates the Simple View of Reading, including key components - word reading and listening comprehensionand the skills that underpin both.

Numerous studies support the Simple View. They show that word reading and listening comprehension are relatively independent of each other, but both contribute significantly to reading comprehension (e.g., Aaron, Joshi, \& Williams, 1999; Catts, Hogan \& Fey, 2003; de Jong \& van der Leij, 2002; Hoover \& Gough, 1990; Singer \& Crouse, 1981 ). Furthermore, the contribution of individual differences in decoding and listening comprehension to reading comprehension varies across grades (Aaron et al., 1999; Catts et al., 2005). In the early grades, reading comprehension is heavily dependent on emerging decoding skills. As these skills become automatized, language abilities serve as a more critical determinant of one's reading comprehension (Adlof, Catts, \& Little, 2006). This finding explains the oftnoted educational phenomenon in third or fourth grade when children shift from learning to read to reading to learn (Chall, 1983).

Thus, beyond decoding, language skills serve as "pressure points" in listening comprehension, which account for individual differences in skilled reading comprehension as well as reading comprehension difficulties (Perfetti, 2009). Central to the Simple View is the idea that the language skills that support reading comprehension are essential for successful language comprehension; children need these skills to understand complex directions, stories, and conversations. Longitudinal studies of children with reading or language difficulties or both support this viewpoint. If language abilities are crucial for accurate reading comprehension, we would expect that children who have reading comprehension difficulties would also have poor language skills. Indeed, language weaknesses serve as well-documented precursors to comprehension difficulties. Longitudinal research involving retrospective analyses of the language history of children with deficits in reading comprehension shows that as many as $70 \%$ of chil-
Figure I. Visual representation of the Simple View of Reading including direct and indirect links to reading comprehension through word reading and listening comprehension.

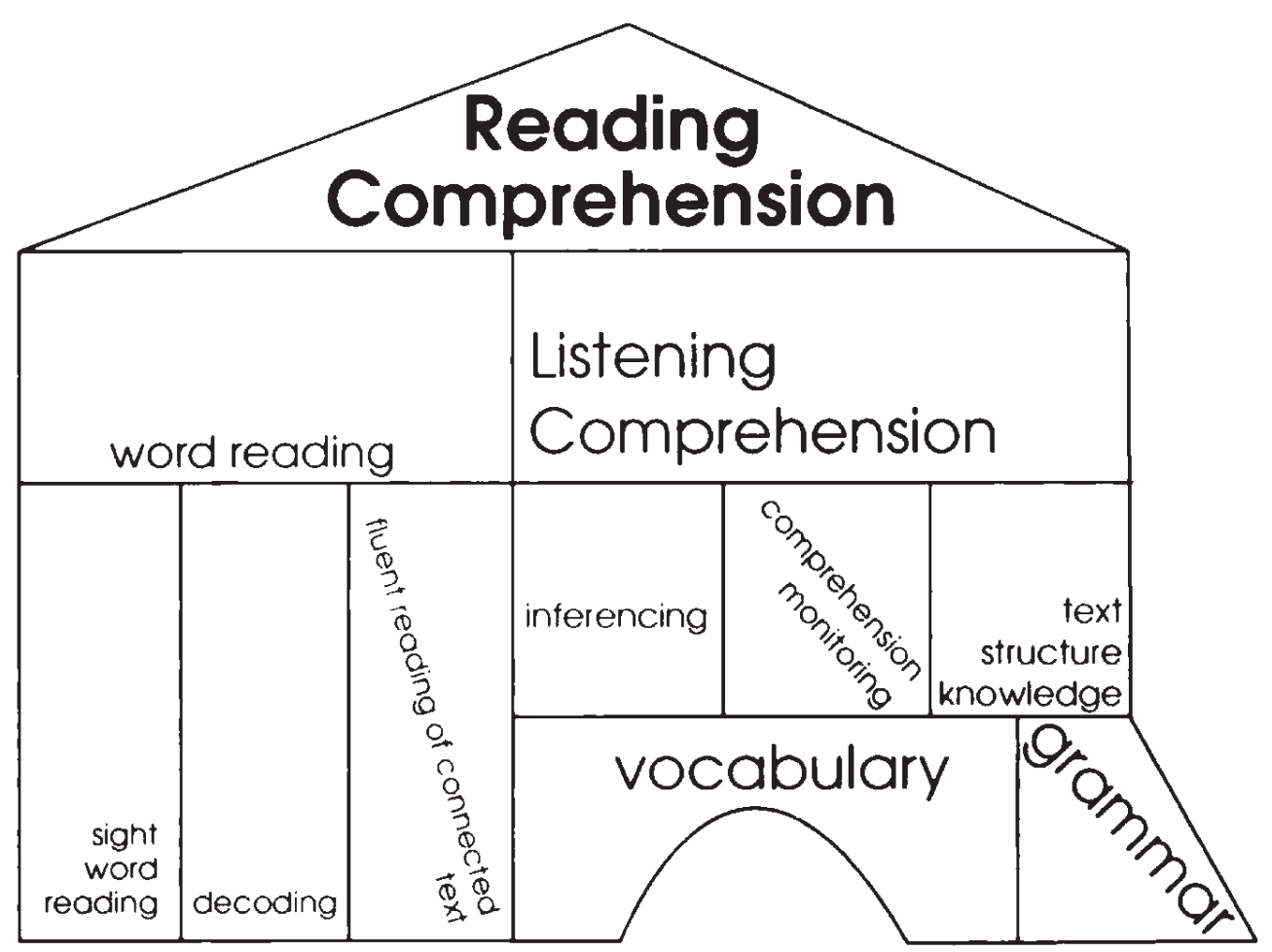


dren who read poorly in second grade had significant deficits in language skills during kindergarten (Catts, Fey, Zhang, \& Tomblin, 1999). A recent report found that fifth graders with poor reading comprehension, despite good word reading, evidenced low language skills as early as 15 months old (Justice, Mashburn, \& Petscher, in press). Similarly, children with language delays during kindergarten face elevated risk of future reading comprehension difficulties (Catts, Fey, Tomblin, \& Zhang, 2002). These children comprise nearly one fourth of kindergarteners, with disproportional representation of children raised in poverty or with disabilities (Hair, Halle, Terry-Humen, Lavelle, \& Calkins, 2006).

\section{Language Skills and Reading Comprehension: Lower Level Language Skills versus Higher Level Language Skills}

Our illustration of the Simple View (Figure 1) shows the range of language skills that contribute to reading comprehension indirectly though their influence on listening comprehension. Good comprehension involves creating a mental representation of a text's meaning. Vocabulary and grammar are clearly essential in the comprehension process, enabling understanding of the words and individual sentences in a text. They are used to construct the representation of the literal meaning of a text, referred to by some as the textbase (Kintsch \& Kintsch, 2005).

Successful comprehenders go beyond single-word and sentence comprehension and the textbase; they construct a representation of the text's meaning that represents the situation or state of affairs described by the text, referred to as a mental model (Kintsch \& Kintsch, 2005). The construction of a mental model of a text involves organizing a text's multiple propositions into an integrated whole and incorporating one's prior knowledge. To do this, successful comprehenders draw upon a set of language skills that are particularly crucial to accurate comprehension because of the integrative role they play in creating a mental model (Cain, Oakhill \& Bryant, 2004; Perfetti, 2007). Take the following example: "Molly carried the glass of juice. She tripped on the step. Mom fetched the mop." The literal representation of the individual words and sentences docs not enable the reader to integrate their meanings and construct a mental model of the text. Successful comprehenders have good knowledge of narrative structure - for example, things happen for a reason - and will use this knowledge to infer that Molly spilled the juice. Therefore, they understand why Mom fetched the mop. Successful comprehenders monitor their understanding of the text and, in doing so, realize the need to make an inference-that Molly spilled the juice-to make sense of Mom's actions.

In this paper, we refer to vocabulary and grammar as lower level language skills for two reasons. First, they emerge relatively quickly and easily for the majority of children during the course of early childhood. Second, lower level language skills serve as the foundation that supports what have been labeled higher level language skills, which are required to construct a mental model of a text's meaning. These higher level language skills are inferencing, comprehension monitoring, and text structure knowledge. In research, these are collectively and variously referred to as "higher level meaning construction skills" and "higher-level factors in comprehension" (respectively, Cain, Oakhill, \& Bryant, 2004; Perfetti, Landi, \& Oakhill, 2005). Theoretically, when lower level language skills are well specified and coherently organized (i.e., verbally efficient; Perfetti, 2007) one is able to draw on higher level language skills, which result in better reading comprehension. Furthermore, the reverse is also plausible: as children develop higher level language skills, their ability to create accurate mental models advances their vocabulary and grammar.

Even when children show similar vocabulary, grammar, and word reading abilities, higher level language skills are poorer in school-age children with poor reading comprehension compared to those with good reading comprehension (e.g., Cain \& Oakhill, 2006; Catts, Adlof, \& Ellis Weismer, 2006; Nation, Clarke, Marshall, \& Durand, 2004). Tests of higher level language skills are also correlated with reading comprehension in 8- to 11-year-old children's reading comprehension (Cain, Oakhill, \& Bryant, 2004; Oakhill \& Cain, in press). However, higher level language skills are not exclusive to reading; children begin developing these skills before formal reading instruction. Because these skills are not reliant on word reading abilities, they can be stimulated across a child's educational career-preschool through high school (and beyond)-through different modalities (e.g., spoken, sign) and with a range of texts. These skills are used extensively in a range of language comprehension situations outside of reading. For example, we use inference and monitoring skills and text struc- 
ture knowledge to follow a set of instructions; understand spoken narratives, cartoons, and movies; and to relate autobiographical accounts of everyday activities around the dinner table. In addition, the construction of the mental model of a text enabled by higher level language skills provides the context in which to interpret each new word or sentence, enabling successful comprehenders to select the appropriate meaning of a word with multiple meanings (e.g., bank, bat) or to interpret a string of words figuratively rather than literally (e.g., to take the bull by the horns).

\section{Inferencing, Comprehension Monitoring, and Text Structure Knowledge Assessment and Instructional Techniques}

In the following sections we detail specifically the higher level language skills of inferencing, comprehension monitoring, and text structure knowledge. We then provide examples of how these skills are commonly assessed, and we review evidence-based instructional techniques to stimulate each. Finally, we end this section with a sample lesson plan using an early childhood shared storybook reading context, which incorporates the techniques we describe to stimulate inferencing, comprehension monitoring, and text structure knowledge. We chose to focus on stimulating these skills in young children through shared storybook reading for two reasons: (a) these skills develop from a very early age and their development is not dependent on word reading, and (b) these skills can be supported in older children who struggle to decode. Moreover, stimulating these skills aids the development of many aspects of language processing (e.g., understanding and sharing oral narratives, understanding and giving complex instructions, etc.), not just those related to text comprehension. As a result, stimulating higher level language skills provides an ideal opportunity to foster reading-related comprehension skills at a higher level of language in young prereaders, in those who struggle with decoding, and to a whole class of children with different levels of decoding abilities. Although we illustrate several evidence-based techniques for stimulating higher level language skills during book reading, we are unable to overview all that may be useful. Table 1 provides numerous techniques for further reference.

\section{Inferencing}

When children develop a mental model of a text, they draw upon higher level language skills that help them consolidate multiple propositions into an integrated whole (see Kintsch \& Kintsch, 2005). Among the higher level language skills serving this integrative role is that of inferencing, also referred to as inferential language. Inferencing helps one to fill in the gaps and go beyond the literal meaning of words on the page to create a comprehensive mental model (Bowyer-Crane \& Snowling, 2005). For example, a story may describe a crying boy holding his bleeding foot, surrounded by broken glass and a banana peel. Although not explicitly stated in the text, one might infer that the child slipped on a slick banana peel while carrying a glass, the glass broke from the fall, and he cut his foot. As illustrated in this example, the ability to make inferences relies heavily on possessing the appropriate schema, or background knowledge, to comprehend written text. It is also considered a cognitive skill in its own right. As they read, skilled readers make a greater number of inferences while creating mental models of text as compared poor readers; in fact, a failure to adequately draw inferences, as observed in poor readers, results in incomplete or inadequate mental comprehensive models, (which in turn negatively mental model affects comprehension - see Cain, Oakhill, Barnes, \& Bryant, 2001). The ability to adequately draw inferences when reading is therefore considered an essential component of skilled reading comprehension (Cain et al., 2001).

The ability to draw inferences from text has rarely been studied with young children (prereaders). Rather, much of the research on young children's comprehension - typically within listening tasks (e.g., listening to a story) since young children are likely unable to read-has focused on literal comprehension, or the child's ability to recall basic facts or concepts presented in a text or its pictures. For instance, children may be asked to recall perceptual features of objects or events (e.g., "Where did the boy find his teddy bear?" "What was the girl wearing?"). While such questions can examine children's basic comprehension of text, they do not examine (or promote) children's integrative processing of text because they do not require inferencing. An inferential discussion, as well as inferentially-oriented comprehension questions, goes beyond that which is directly stated in the text. For instance, children might be asked questions related to a character's mental state or actions that 
Table I. Empirically Validated Techniques for Stimulating Higher Level Language Skills

\begin{tabular}{|c|c|c|c|}
\hline \multirow{3}{*}{ Inferencing } & Interpretative cloze & Prekindergarten- Kindergarten & $\begin{array}{l}\text { Bradshaw, Hoffman, \& Norris, 1998; } \\
\text { van Kleek et al., } 2006\end{array}$ \\
\hline & Content highlighting & Grades I-3 & $\begin{array}{l}\text { Beck, Omanson, \& McKeown, I982; } \\
\text { Yuill \& Oakhill, I } 988\end{array}$ \\
\hline & Use key/clue words & Grades I-3 & Beck et al., 1982; Yuill \& Oakhill, 1988 \\
\hline \multirow{3}{*}{$\begin{array}{l}\text { Comprehension } \\
\text { Monitoring }\end{array}$} & Self-questioning training & Prekindergarten- Kindergarten & Glaubman, Glaubman, \& Ofir, 1997 \\
\hline & Questioning the Author & Prekindergarten- Grade 3 & Beck \& McKeown, 2006; Beck et al., 1996 \\
\hline & $\begin{array}{l}\text { Semantic ambiguity } \\
\text { instruction }\end{array}$ & Grades I-3 & Baker \& Zimlin, 1989; Zipke et al., 2009 \\
\hline \multirow[t]{2}{*}{$\begin{array}{l}\text { Text Structure } \\
\text { Knowledge }\end{array}$} & Clue words & Prekindergarten- Grade 3 & $\begin{array}{l}\text { Williams, Goldstein, \& Minshew, 2005; } \\
\text { Gillam, Gillam, Petersen, \& Bingham, 2008; }\end{array}$ \\
\hline & & & $\begin{array}{l}\text { Westerveld \& Gillon, 2008; } \\
\text { Yuill \& Oakhill, I } 988\end{array}$ \\
\hline
\end{tabular}

are not explicitly stated in the text, such as, "How do you think he felt when he could not find his teddy?" Other inferential questions might require children to predict what course of action a character might take (e.g., "Where do you think the boy should go next?"). These questions require children to use their background knowledge coupled with inferencing skills to provide a feasible, accurate response.

The inferencing skills of young children with respect to text comprehension have rarely been studied, and, when reading with children, adults rarely promote children's inferencing skills (e.g., through the questions they ask). However, increasing evidence shows that young children are quite capable of generating inferences when listening to texts and can be readily supported to do so during shared-reading experiences (e.g., van Kleeck, Vander Woude, \& Hammett, 2006; Zucker, Justice, Piasta, \& Kaderavek, 2010).

Readers rely upon three types of inferences to accurately comprehend text, our descriptions of which are adapted from Bowyer-Crane and Snowling (2005). The first type is the cohesive inference (also called the coherence inference), in which the reader uses linguistic knowledge to draw connections within the text. For instance, readers' mental representation of the sentences, Sally got the cat a drink. He drank the milk noisily. integrates information across both to derive a mental model in which the drink Sally brought was milk, although this was not explicitly stated. Here, the reader uses language skills to infer that he refers to the cat (although this was not stated either).

The second type of inference is knowledge based, in which the reader must draw upon background knowledge to develop a coherent and accurate mental model of the text's content. For instance, to comprehend the text, A number of people did not get the email and therefore failed to show at the party, one needs to make the inference that the email contained an invitation to the party. If this inference is not made (which requires some background knowledge re- 
garding email, invitations, and parties), one simply cannot comprehend this text or the relations between the two clauses.

Finally, the third type is the evaluative inference, in which the reader uses background knowledge to draw connections between events within a text in order to understand a character's emotions, motivations, and goals (van den Broek, 1997). For instance, to comprehend the text, No one came to the party. Nancy threw away the cake, one might infer that because no one came to the party, Nancy was upset and, in turn, threw away the cake (rather than eating it or saving it).

When they occur in text, these types of inferences can be differentiated into two categories: those that help one to make connections between different sentences and clauses (i.e., text-connecting inferences) and those that help one to fill in details missing from the text (i.e., gap-filling inferences; Cain \& Oakhill, 1999). In general, cohesive inferences help one to make inferences that connect elements of text, whereas knowledge-based and evaluative inferences help one to fill in missing information. Typically, children are better able to make text-connecting inferences than gap-filling inferences (Cain \& Oakhill, 1999).

\section{Assessment}

To assess inferencing and examine comprehension, the most common approach is to have a child read stories and then answer simple questions about the story. Typically, these questions are of two types: questions about literal content of the text and questions that require inferences (Bowyer-Crane \& Snowling, 2005). The inclusion of questions about literal content is important for assessing a child's basic comprehension of a text. If a child is unable to comprehend the literal content of a text, it is likely that comprehension involving inferencing will suffer as a result. On the other hand, if a child is able to comprehend the literal content of a text well but otherwise has difficulties with inferencing, this might suggest comprehension difficulties specific to inferencing.

Inferencing-type questions typically require children to go beyond the text to determine whether they are able to answer questions using different types of inferences. For instance, one study that involved 7- to 8 -year-olds required the children to read short passages and then, for each, answer one question that examined their ability to draw cohesive inferences
("What did Dack wish?") and one question that examined their ability to draw an elaborative inference ("What did Dack and Tane take out of their bags?"; see Cain et al., 2001). Although these studies involved children of reading age, the passages were presented orally to the children (as in Cain et al., 2001; see also Barnes, Dennis, \& Haefele-Kalvaitis, 1996), demonstrating that this format could he used for nonreaders. Such tasks can be created quite easily and appear to be sensitive to identifying when and under what circumstances children have difficulties drawing inferences.

For children who are not yet readers, such question-answer tasks can be integrated into shared book-reading experiences. For example, children could participate in a shared-reading experience, and inferential questions that involve text-connecting and gap-filling inferences could be embedded directly into the story routine. Young children are readily able to respond to cognitively challenging questions embedded into shared-reading experiences that are of an inferential nature (Zucker et al., 2010). Assessments of young children's language and literacy skills that embed tasks within sharedreading experiences are both valid and reliable (Justice, Bowles, \& Skibbe, 2006), and thus this approach warrants further exploration as a means for assessing the inferencing skills of young children. Table 2 includes a sample story and comprehension questions, adapted from Cain \& Oakhill (1999). Questions assess children's ability to recall content stated in the text (i.e., literal questions) and construct two types of inferences, text-connecting inferences and gap-filling inferences.

Think aloud protocols can be used as an alternative to integrating question-answer tasks into shared book-reading experiences. To implement a think aloud, one would train children to think aloud about a story when prompted, for example, by a picture of a child with a thought bubble above his head. Before reading a story, children would be shown the picture while listening to these instructions, adapted from Lynch and van den Broek (2007):

Usually we just think inside our heads without saying what we are thinking. But today, we are going to play a game where you get to say just what you are thinking. We are going to listen to some stories, and every time we see this picture, we are going to stop and you will say what you are thinking. (332) 
Table 2. Sample Story with Accompanying Questions Assessing Child's Ability to Recall Literal Information Stated in the Story and Questions Addressing Two Inferences:TextConnecting and Gap Filling

Debbie was going out for the day with her friend Michael. By the time they got there they were thirsty. Michael got a drink out of his backpack and they shared it. The orange juice was refreshing. Debbie put on her swimming suit, but the water was too cold to swim in, so they made sandcastles instead.

They played all afternoon and didn't notice how late it was. Then Debbie spotted the clock on the pier. If she was late for dinner, her parents would be angry. They quickly packed up their things. Debbie changed and wrapped her swimming suit in her towel. She put the bundle in a plastic bag. Then they set off for home, pedaling as fast as they could. Debbie was very tired when she got home, but she was just in time for dinner.

\section{Questions}

\section{Literal information:}

I.Who did Debbie spend the afternoon with?

2.Where was the clock?

\section{Text-connecting inference:}

3.Where did Michael get the orange juice?

4.Where did Debbie put her towel when she packed up her things?

\section{Gap-filling inference:}

5.Where did Debbie and Michael spend the afternoon? 6. How did Debbie and Michael travel home?

Source: Adapted from "Inference Making Ability and Its Relation to Comprehension Failure," by K. Cain and J.V. Oakhill, 1999, Reading and Writing, II, 489-503.

At various points when reading a story, the children would be shown the picture of the child with a thought bubble and asked a general question such as "What are you thinking about now?" Children's responses to these probes can be evaluated to determine whether they included an inference. In one study employing think-aloud protocols with 6- and 8-year-olds, children listened to a story accompanying the wordless picture book Frog, Where are you? (Mayer, 1969). General probes like the one above were inserted into the story six times to examine children's inferences about the goals of characters (Lynch \& van den Broek, 2007). An example of a goal that a child may state during his or her think aloud is that the boy in the story is worried that he has lost his frog therefore his dog is trying to find the frog. The results of this study, which found that children's goal-based inferences are significantly associated with overall story comprehension (i.e., children who produce more inferences had better comprehension), also indicated that the use of thinkaloud protocols can be a viable way to assess inferencing skills in young children.

\section{Instructional supports}

The consistently observed relations between inferencing and reading comprehension, coupled with findings showing that children who are poor comprehenders have difficulty making inferences when reading (Cain \& Oakhill, 1999), have drawn attention to the importance of supporting inference development even among very young children (see van Kleeck, 2008). Research on how to support young children's production and comprehension of inferential language has drawn on a large research base showing that shared-reading activities present a salient opportunity to systematically and explicitly boost children's skills in a variety of language and literacy domains, including vocabulary (e.g., Penno, Wilkinson, \& Moore, 2002) and print awareness (Justice \& Ezell, 2002). This body of work has shown that adults, such as parents and teachers, can embed conversational routines into shared-reading activities that explicitly teach children specific concepts. For instance, in the area of vocabulary, adults can explicitly teach children the meaning of conceptually challenging words by identifying the word, defining it, and encouraging children to use it in a sentence (e.g., Penno et al., 2002). Embedding explicit teaching within shared-reading activities is a generally desirable approach when delivering language and literacy interventions to young children, as these activities provide a naturalistic and developmentally appropriate context with which children tend to be highly engaged and motivated.

In general, identification of ways to improve young children's inferential language skills has lagged behind developmental research in this area. However, two recent studies provide guidance for how educators can explicitly address inferential language within the context of shared-reading interactions. It is important to note that the participants in both studies were preschool-aged children experiencing developmental delays; therefore, we can make some tenable generalizations regarding the applications of these findings to young children with disabilities. The first study involved systematic observation of group read alouds in 25 early childhood classrooms serving children at risk, three of which were special education inclu- 
sion classrooms. The study findings showed that during read alouds there was a strong sequential dependency between teachers' questions of an inferential nature and children's responses. That is, when teachers asked a question that required inferencing (e.g., "Why does he need to buckle up?"), children's immediate responses tended to reflect that level of cognitive demand (e.g., "Because the airplane is about to move"; Zucker et al., 2010, p. 77).

Such findings are compelling, as they suggest that teachers' expression of inferential language during book reading (and perhaps other activities) directly elicits inferencing from children, which in turn may improve this important contributor to future reading comprehension. This likelihood is strengthened by findings presented by van Kleeck et al. (2006) in which researchers conducted a book-reading program in Head Start classrooms. In this work, fifteen 3to 5-year-old children with specific language impairment (SLI) participated in experimental one-on-one book-reading sessions twice per week for an 8-week period. Within each session, the adult readers (research assistants) embedded eight questions of an inferential nature, like "How do you think Bear feels because his friend Little Bird is leaving?" (95). Children in a control group received normal classroom instruction. Analysis of pretest and posttest language assessments showed that children who participated in the experimental reading sessions experienced significant improvements in their vocabulary skill and their understanding of inferential language. Coupled with the Zucker et al. (2010) study identifying the evocative power of teachers' inferentially focused questions, this work suggests that encouraging children to have conversations of an inferential nature-predicting future events in a story, filling in the gaps, and focusing on character intentions and feelings - is a viable means for fostering this higher level language skill.

\section{Comprehension Monitoring}

Another higher order language skill, comprehension monitoring, involves the capacity to reflect on one's own comprehension and includes the ability to detect inconsistencies within a text. It is important to note that a failure of comprehension or of detection of inconsistencies may in fact stem from lack of general knowledge rather than a failure to monitor comprehension. Good readers are typically aware of their comprehension as they read or listen to written text, and, when they experience difficulty, they automatically use a variety of strategies, such as rereading, to increase their comprehension (Pressley \& Afflerbach, 1995). However, young children and those who struggle to comprehend are likely to have difficultly monitoring their comprehension independently because it requires significant cognitive resources, such as memory and attention.

\section{Assessment}

Comprehension monitoring is typically assessed with an error detection task. Children read or listen to some text that contains anomalous or contradictory information, such as a novel word, a proposition which conflicts with prior knowledge, or two propositions in the text that conflict in meaning (Baker, 1984). The ability to detect these errors is assessed by asking the child whether the text makes sense, to identify any parts that do not make sense, or both. For example:

\footnotetext{
Yesterday Martha and her family went to their favorite restaurant. Martha always ordered the same thing-steak and French fries! The waiter put the plates on the table. Martha cut into her steak with scissors. It tasted delicious.
}

A child with good comprehension monitoring skills would detect the inconsistency in this story based on knowledge of the world that you don't cut steak with scissors - whereas a child with poor comprehension will not.

Early research suggested that young readers rarely spot inconsistencies and, by implication, do not adequately monitor their comprehension. For example, Markman (1979) found that 8- to 11-year-olds detected internal inconsistencies in a text-two contradictory propositions - on fewer than half of all occasions. This type of error detection requires adequate memory processing resources. However, when children are instructed that passages contain errors, the ability to detect a range of errors is evident even in 5-year-olds (Baker, 1984). In addition, when the task is made more interesting, young readers' comprehension monitoring improves (Baker, 1984; de Sousa \& Oakhill, 1996). With the appropriate resources, comprehension monitoring can be assessed in prereaders. For example, children between 30 and 48 months show signs of monitoring, expressing surprise when an actor or the temporal order of events is changed during the narration of a familiar story book (Skarakis-Doyle, 2002). Thus, comprehension monitoring can be assessed in prereaders with the appropriate materials and method. 


\section{Instructional support}

Because of the importance of comprehension monitoring to reading comprehension, instructional support of developing comprehension monitoring should be included in comprehension instruction. One method for encouraging comprehension monitoring is to ask children to summarize a story at different points while listening or reading (Applebee, Langer, Nystrand, \& Gamoran, 2003). Summarizing requires that a child identify the most salient parts of a story and then retell that information in his or her own words. Asking a child to periodically summarize portions of a text will alert the child to aspects of the story that he or she did not understand. The teacher can then draw the child's attention to inconsistencies between the summary and the text, if present. Further, teachers can model summarizing by periodically stopping to recap main ideas at predetermined points in a text. The teacher may use sabotage (i.e., provide misinformation in the summary), while encouraging the students to point out inconsistencies between the summary and the text. Baumann, Seifert-Kessell, and Jones (1992) found that encouraging third graders to use comprehension monitoring techniques through teacher-based think alouds was effective at improving their ability to monitor incongruencies in texts.

Another method for increasing comprehension monitoring involves Questioning the Author (QtA; Beck \& McKeown, 2006; Beck, McKeown, Sandora, Kucan, \& Worthy, 1996). QtA involves the teacher stopping at predetermined points in a text to ask open-ended questions. Stopping points are chosen to promote comprehension monitoring, such as when a key character is introduced, an important event has occurred, or where there is possibility of reader confusion. After asking a question, the teacher promotes discussion of the text to answer the question. The use of QtA encourages children to actively engage in text comprehension that, in turn, improves their ability to detect their breakdowns in comprehension (McKeown, Beck, \& Blake, 2009).

\section{Knowledge of Text Structures}

Text structure refers to how a written text is organized to guide reader comprehension. To be able to understand written text, one must be able to recognize relationships among elements in text (Graesser \& Clark, 1985; Langston \& Trabasso, 1998). When one is able to recognize relationships across both sentences and larger units of text, one is able to form a mental model of what was read. Researchers have suggested that increasing students' knowledge of text structure facilitates their ability to attend to the most salient details in the text, therefore increasing comprehension (e.g., Carnine \& Kinder, 1985; Gersten, Fuchs, Williams, \& Baker, 2001). Text structure is typically described according to two types of written work: narrative texts and expository texts. Although some characteristics overlap between the two, the structural patterns are quite different. Knowledge of both structures provides a framework in which readers can more readily anticipate elements to guide comprehension.

A narrative can be described as text that relates a story or a sequence of events. Narratives, unlike expository texts, need not be factual and are often written from the perspective of a character in the story. Narrative texts are generally believed to be easier for students to comprehend than expository texts. Gersten and colleagues (2001) suggested two reasons for this. First, the content in narratives is typically familiar to children and often closely parallels activities in their daily lives, such as going to a department store or trying to find a lost pet. Secondly, narratives generally follow the same predictable structure, often referred to as story grammar. Most stories include basic elements such as a setting, introduction of characters, a goal or actions related to the goal, internal reactions of the characters, and a resolution or ending (Mandler \& Johnson, 1977; Stein \& Trabasso, 1982). These elements are typically strung together in a particular order, and, in the case of a story with multiple episodes, the elements maintain the same order across episodes. Children can use their knowledge of these predictable components to help make sense of a text and to make predictions about what might happen next. For example, if a storybook describes a setting as a particularly dark and stormy day, this might prompt a child to anticipate that the stormy day will play an important role in the events that will occur.

Expository, or informational, texts contain factual information and are typically written in order to inform or explain something to the reader. Like narrative texts, expository texts also involve important elements; however the structure of this type of text varies. Englert and Thomas (1987) described four common structures in expository text: comparison/ contrast, collection, sequence, and problem/solution. Anderson and Armbruster (1984) detailed a similar but slightly expanded list: description, temporal sequence of events, explanation of concepts, definition 
and example, compare and contrast, and problem-solution-effect. Expository text is viewed as more difficult than narrative text (Goldman \& Rakestraw, 2000) and generally contains more unfamiliar vocabulary and concepts and is less directly related to students' personal experiences. However, expository text becomes increasingly important across the school years, and by fourth grade the majority of content students are expected to learn is presented in informational books (Moss, 2004).

In most classrooms, narratives are prevalent and expository texts are neglected. A landmark study by Pappas (1993) encouraged educators to rethink this emphasis on narrative text with young children. In this study, kindergarten children were as adept at reenacting information from informational books as they were from stories. Furthermore, when asked, they preferred the informational books over the stories. This was one of the first studies to challenge the notion that narratives should be the primary type of text structure with young children. The "narratives as primary" idea was also highlighted in a report by Duke (2000), who examined first-grade classroom libraries and found that narrative books overwhelmingly outnumbered nonfiction texts. This is regrettable, as studies have highlighted the benefits and success of using nonfiction in the early grades (Doiron, 1994; Duthie, 1994; Pappas). Moreover, these studies, as well as later ones (Caswell \& Duke, 1998; Palmer \& Stewart, 2003), confirmed Pappas's finding that young students often display a preference for nonfiction texts.

Research with older students has shown that explicit instruction in text structure can help students comprehend expository text (e.g., Bakken, Mastropieri, \& Scruggs, 1997; Dickson, 1999). This research has been relatively absent with younger students. One exception is recent work by Williams and colleagues, which has shown that the explicit instruction of text structure can positively affect students' comprehension of expository text (Williams, Stafford, Lauer, Hall, \& Pollini, 2009). In this study, the researchers evaluated the effects of teaching the compare/contrast structure to second-grade students with a series of reading comprehension lessons. The content goal of the program was to teach students about animal classification. All students received this content instruction, but only some of the students received the additional text structure instruction. The authors wrote text specifically designed with the compare/contrast structure in mind, thus diminishing the problem of finding well-suited texts to use in their content area. Their findings demonstrated that explicit text structure instruction was effective at improving reading comprehension. An additional finding suggested that this instruction did not negatively affect the amount of content acquired by the students. This was one of the first studies of its kind showing that children in the primary grades are able to benefit from explicit instruction in expository text structure; future research is warranted to examine this type of instruction with younger students and across different expository structures.

\section{Assessment}

One of the most common methods used to assess knowledge of narrative structure is to ask questions related to the important components of a story, such as characters, the goal or problem, and the resolution. This can be accomplished informally by having a student first read a story. (Younger students can listen to a story read to them if needed.) Teachers can then ask students to answer questions about specific information related to story grammar elements. A more difficult method of assessment is retelling or summarizing. Lipson and Wixson (1986) provided a list of probe questions that might help a teacher elicit important story components:

- What happens to get the story started?

- What did do __ about___ ?

- What makes it difficult for the characters to solve their problem?

- How is the problem solved?

For younger children, the emphasis should be on the more salient portions of the story, such as the setting, characters, a major action or problem in the story, and the ending. For older children, teachers should request more sophisticated details, such as information related to the characters' goals or feelings. In the case of expository text, students can be asked questions related to both the components of the text and its content. For example, students may be asked to identify parts of an informational book, aside from the text, that help them learn the content, such as illustrations, charts, or tables.

\section{Instructional Supports}

Providing visual representations, such as story maps, can assist children in comprehending text. A story map is a type of graphic organizer that helps 
students learn the important elements of a story. Story maps have been utilized to increase reading comprehension skills by prompting students to recognize story-grammar elements such as character, setting, and problem (Dimino, Taylor, \& Gersten, 1995) and to make connections between story components (Pearson, 1982). Basic story maps can focus on the beginning, middle, and end of a story, while a more complex map can delve into character traits or intricacies of the plot. It is important that teachers initially model how to complete a story map. Additionally, teachers may need to stop students at critical points in a narrative and ask them about story elements. Figure 2 illustrates story maps varying in complexity.

Visual representations can also help students comprehend expository text. Graphic organizers used for expository text can include flow charts and timelines and can be used to help students detail actions leading up to an event, such as the events leading up to the Civil War. Other graphic organizers can help students compare and contrast items or define important concepts. For example, in one study (Williams et al., 2007) a graphic organizer was used as part of comprehension instruction to help elementary students visually organize the important elements (i.e., cause, effect, and clue word) of a cause/ effect sentence.

Another way to increase knowledge of expository text structure is to simply provide more experiences for listening to and reading information books. As discussed previously, there is a paucity of expository textbooks in early childhood and primary grade classrooms. Children should have appropriate and extensive exposure to informational texts in their classrooms. However, educators and researchers have noted the limited number of accessible, wellwritten informational texts. Because of this, teachers should carefully select appropriate informational texts. Saul and Dieckman (2005) provided guidance on the selection of informational texts. They noted that associations such as the National Science Teachers Association used the following criteria to choose appropriate science-based informational texts: a) The book has substantial science content; b) information is clear, accurate, and up to date; c) theories and facts are clearly distinguished; d) facts are not oversimplified so that the information is misleading; e) generalizations are supported by facts and significant facts are not omitted; f) books are free of gender, ethnic, and socioeconomic bias. Addition- ally, they suggested choosing informational texts that will spark a sense of wonder and exploration in the reader. In choosing these texts, considering the child's interests may be crucial for engagement and motivation.

\section{Example Lesson Plan: Increasing Higher Level Language Skills through Shared Reading}

Table 3 provides an example lesson plan for stimulating higher level language skills within the context of shared reading. Note that although we focus on higher level language skills, lower level language skills, such as vocabulary and grammar as well as word reading, could be easily incorporated to create a more complete reading comprehension lesson. We use shared book reading involving dialogic reading as our instructional framework (Whitehurst \& Lonigan, 1998). Dialogic reading involves an interactive discussion around text to encourage children to become actively involved in the reading process. PEER - Prompt, Evaluate, Expand, and Repeat-is an acronym for the key components of dialogic reading. First, a prompt is provided in the form of a question about the story. Next, the teacher evaluates the child's response for accuracy and complexity. The teacher then expands on what the child says, with a focus on providing an accurate response if one was not provided by the child. Finally, the original question is repeated to encourage the child to repeat or expand his or her response. Dialogic reading has a large empirically-validated evidence base: Children engaged in dialogic reading show improved vocabulary and story retell (Whitehurst, Falco, Lonigan, \& Fischel, 1988; Zevenbergen, Whitehurst, \& Zevenbergen, 2003).

Our lesson is divided into activities before, during, and after reading. An example of a before-reading activity might be teaching relevant background knowledge for use while inferencing (e.g., Clark, Snowling, Truelove, \& Hulme, 2010) or explicit instruction in comprehension monitoring strategies (e.g., Paris \& Jacobs, 1984). After-reading activities often involve questioning, such as asking readers to identify the main point (see McKeown et al., 2009, for a discussion). During-reading activities may involve explicit instruction in text structure knowledge (e.g., Bakken et al., 1997). 


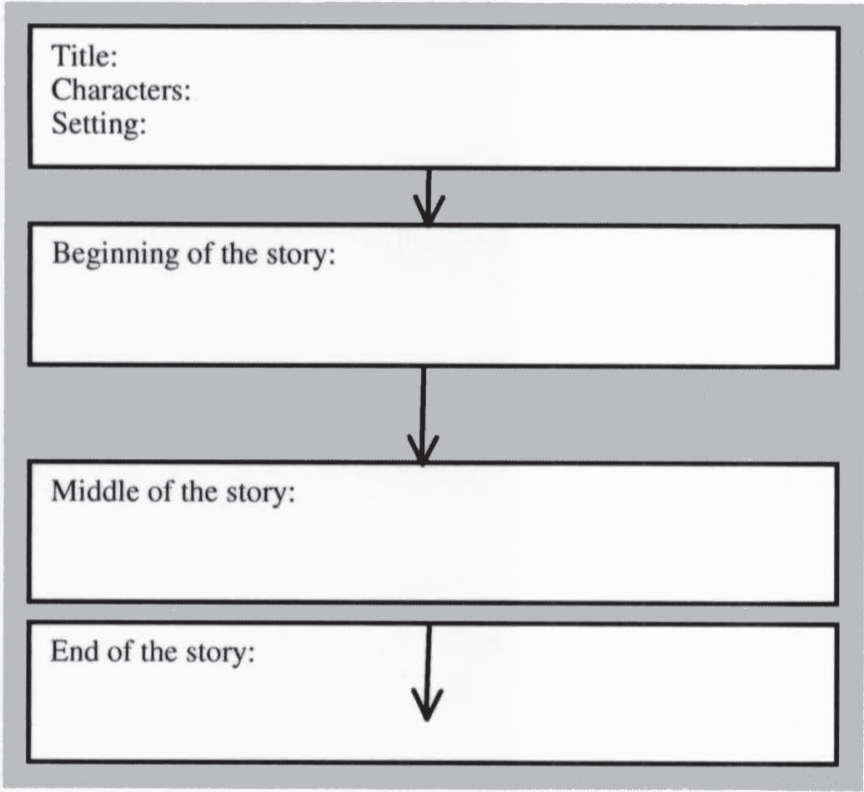

\section{Title:}

Characters:

Setting:

Goal:

Problem:

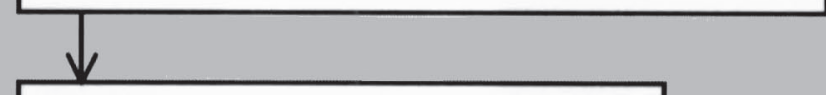

\section{Attempt:}

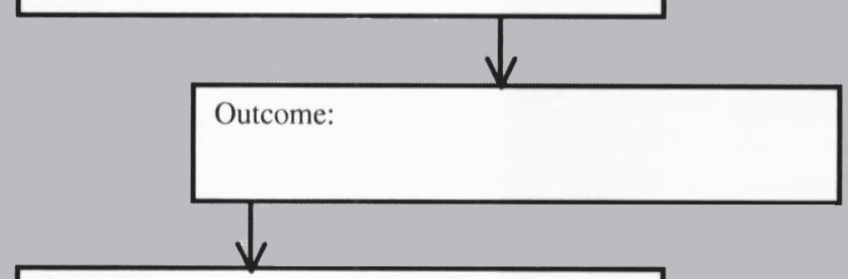

Title: What is the title of the story?

Characters: Who are the main characters?

Setting: Where and when did the story take place?
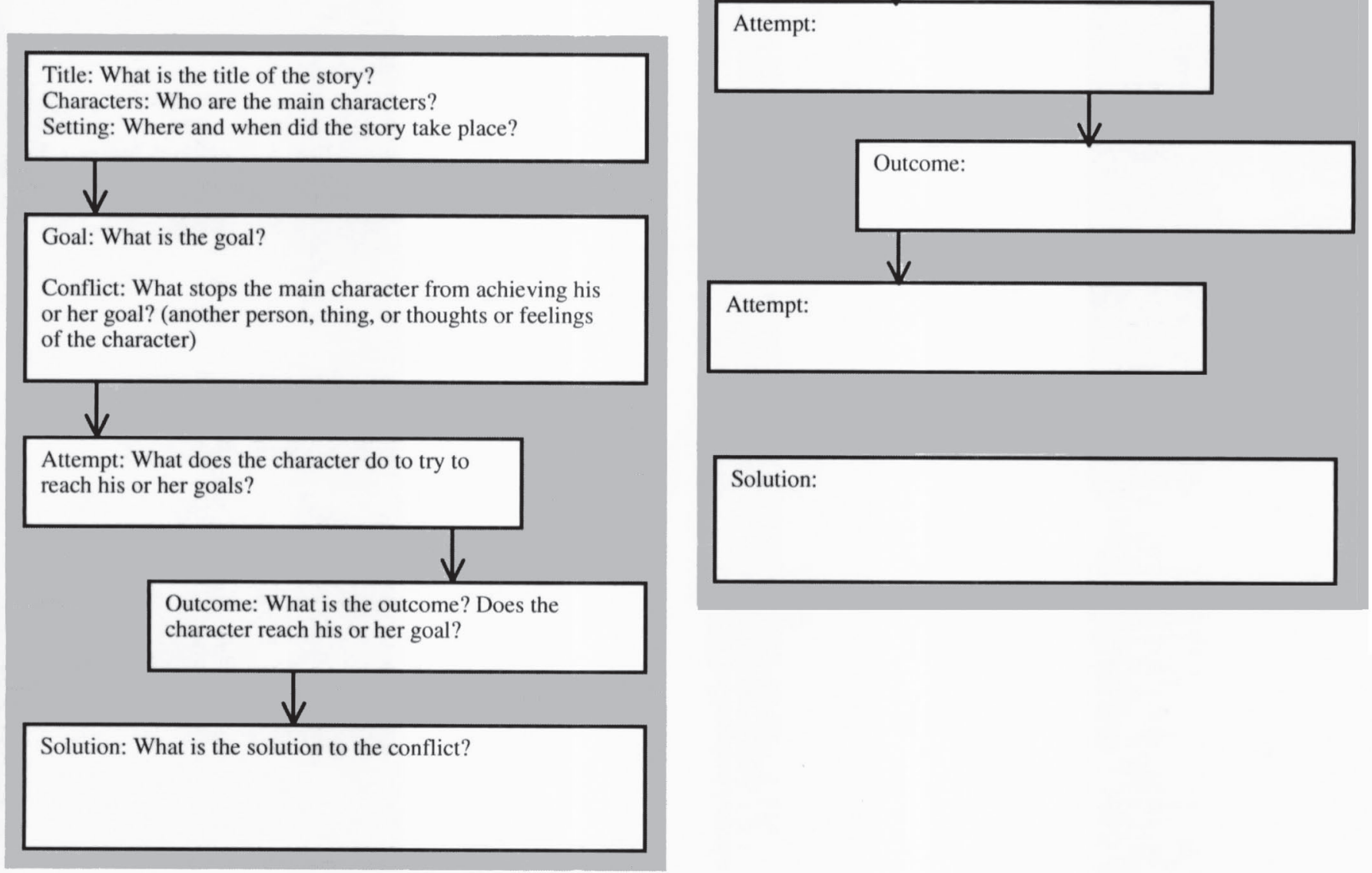

Figure 2. Story Maps Varying in Complexity. 
Table 3. Example Lesson Plan for Improving Higher Level Language Skills using Guji Guji (Chen, 2003).

\section{Higher Level Language Skills Targeted: Instructional Techniques:}

- Inferencing

- Comprehension monitoring

- Text structure knowledge
- Dialogic Reading (Whitehiurst \& Lonigan, 1998)

- Inferential Questioning (Zucker, Justice, Piasta, \& Kaderavek, 2010)

- Questioning the Author (Beck \& McKeown, 2006)

- Rainbow Story Element Organizer (Hogan, Bridges, Wymer, \& Volk, 2010)

\section{Materials:}

Text: Guji Guji (Chen, 2003)

During Reading: Rainbow Graphic

After Reading: Large easel or laptop projected on screen

\section{Story Lesson}

\section{Before Reading}

- Activate background knowledge to improve comprehension monitoring

- Based on the book cover, what do you think this story is going to be about? What do you know about alligators? What do you know about ducks?

\section{During Reading}

- Identify text structure elements to improve text structure knowledge

- Let's use our rainbow to find the key parts of this story. Stop after the first pages. What is the setting of this story? Where does if take place? Let's write it on our first rainbow color, purple. Purple is where we write the setting. Stop on predesignated pages to identify all story elements and write them on the corresponding rainbow color

- Question the author to improve comprehension monitoring

- Stop on predesignated pages to ask questions about the author's wording in the text. For example, Why did the author call Guji Guji a "rather odd-looking duckling"?

-Ask inferential questions to focus on inference making

- Stop on predesignated pages to ask questions that focus on inference making. For example, Why did Guji Guji feel ridiculous when he looked into the water?

\section{After Reading}

- Summarize main points of the story to increase comprehension monitoring with a focus on detecting comprehension breakdowns

- Let's write down the things you remember about this story. What were some of the most important parts of this story? What do you remember most about this story? What surprised you about this story? What will you think about later when you think about this story? 
In our lesson we use the book Guji Guji by ChihYuan Chen (2003). In Guji Guji, an alligator egg rolls into a duck's nest. The alligator egg hatches at the same time as three duck eggs hatch. While the mother duck notes the alligator's differences from her other ducklings, she chooses to raise him as her own. She names him Guji Guji. The story follows Guji Guji's adventures with his duck family. The story was chosen because it requires many inferences, contains clear story elements, and includes several aspects that are easily adapted to encourage comprehension monitoring. The story also encourages acceptance, problem solving, and reflection on the many ways families are created. The first author has found that this text is interesting to many young children. As we have noted, tasks and texts that engage children's interests have been shown to improve performance on higher level comprehension tasks, such as comprehension monitoring, as compared to more traditional drill and skill exercises.

Table 4 provides a list of narrative and information books the authors have found to be appropriate for stimulating higher level language skills in children from prekindergarten through third grade. Any one of these books can be read aloud by an educator in a small or large group to highlight the higher level language components discussed in this paper. These books are not meant to be considered appropriate reading level books for each grade. Indeed, many of the books would be far too difficult for students to read independently. Although we acknowledge the importance of students receiving ample opportunities to practice decoding text, we feel it is also of utmost importance to provide students with experiences with language and story components found in books beyond their reading level. The books listed in Table 4 have interesting and complex language structures which teachers could facilitate through shared book reading with oral discussion throughout, as seen in the example lesson provided in Table 3.

\section{Instructional Considerations}

Even when an intervention is shown to be successful in group comparison designs (e.g., groups that received interventions vs. a no-intervention group), not all children who receive intervention benefit from this support (Torgesen \& Davis, 1996). It is not yet clear why some children fail to respond to an intervention or fail to gain to the same extent as their peers.
A recent meta-analysis demonstrated that IQ did not predict a child's response to different types of reading intervention, suggesting that other factors are important (Stuebing, Barth, Molfese, Weiss, \& Fletcher, 2009). An intervention that targets both lower and higher level language skills may reduce nonresponse by providing a greater opportunity for all children to increase language skills that form the basis of reading comprehension - word reading and language comprehension - as stated by the simple view of reading.

It is not clear whether a particular intervention will be beneficial for all populations with difficulties comprehending text. There are several populations with developmental disorders who experience poor reading comprehension, including individuals with autism spectrum disorder (ASD), Down syndrome, and ADHD. In individuals with ASD, poor comprehension may occur in the presence of hyperlexia, in which word reading skills exceed age-appropriate levels (Nation, 1999). Individuals with ASD have difficulties with the same types of inferential and narrative skills as poor comprehenders without ASD (Norbury \& Bishop, 2002). From that view, it seems plausible that some individuals with ASD, at least, might benefit from the same types of intervention as poor comprehenders. However, individuals with ASD may have more fundamental difficulties processing information (both verbal and visual) in context, a detail-focus processing style described as weak central coherence (e.g.. Happé \& Frith, 2006). Thus, the poor comprehension experienced by this population may have a different underlying cause, and, thus, different interventions may be appropriate.

Another population who experiences poor reading comprehension relative to word reading is children with Down syndrome. This population's reading comprehension level is more strongly associated with their language comprehension skills than with their word reading ability (Roch \& Levorato, 2009), and their language comprehension is a better predictor of subsequent reading comprehension than word reading skills (Roch, Florit, \& Levorato, 2011). On that basis, we might anticipate that the interventions that focus on higher level language comprehension skills will also be of benefit to this group. However, individuals with Down syndrome show an uneven profile of lower level oral language skills, with relative strengths in receptive vocabulary (Chapman, 2006) and weaknesses in morphosyntax (Chapman, 1995). Thus, an intervention that includes both lower and higher level language skills may be most beneficial for this group. 
Table 4. Sample Narrative and Informational Books for Use When Stimulating Higher Level Language Skills

\section{Prekindergarten}

\section{Narrative}

Ehlert, L. (1987). Growing vegetable soup. New York: Harcourt.

Lindbergh, R. (2000). The awful aardvarks shop for school. New York: Puffin.

Martin, B., Jr. (1967). Brown bear, brown bear what do you see? New York: Holt.

\section{Expository}

Ehlert, L. ( 1 992). Planting a rainbow. Glasgow, UK:Voyager.

Gibbons, G. (1987). Trains. New York: Holiday House.

Hoban, T. (1998). So many circles, so many squares. New York: Greewillow.

\section{Kindergarten}

\section{Narrative}

Crews, D. (1986). Ten black dots. New York: Greewillow. Soto, G. (1996). Too many tamales. New York: Puffin Books. Freeman, D. (1980). A pocket for Corduroy. New York: Puffin Books.

Keats, E.J. (1962). The snowy day. New York: Puffin Books.

Wood, A. \& Wood, D. (1984). The napping house. Orlando, FL: Red Wagon Books.

\section{Expository}

Aliki. ( 1991). My five senses. New York: Harper Trophy.

Giganti, P (1992). Each orange had 8 slices. New York: Harper Trophy.

Karas, G.B. (2005). On earth. New York: Putnam.

Sweeny, J. (2000). /We and my amazing body. Albuquerque, NM: Dragonfly Books.

\section{First grade}

\section{Narrative}

Demi. (2007). The empty pot. New York: Holt.

Hutchinson, P (1986). The doorbell rang. New York: Greenwillow.

Lobel, A. (1972). Frog and toad together. New York: Harper Collins.

Sendak, M. (1962). Chicken soup with rice. New York: Harper Collins.
Expository

Bergen, L. (2008). The polar bear's home:A story about global warming. New York: Little Simon.

Gershator, D., \& Gershator, P. (1998). Bread is for eating. New York: Henry Holt.

Rockwell, A. Our stars. Glasgow, UK:Voyager Books.

Sweeney, J. (1998). Me on the map. New York: Dragonfly Books.

\section{Second grade}

Narrative

Brown, M.W. (2005). Sneakers the seaside cat. New York: Harper Trophy.

Gannett, R. S. (1948). My father's dragon. New York: Random House.

Lester, H. (2005). Tacky in Trouble. Boston: Houghton-Mifflin.

Rylant, C. (200I). Poppleton in winter. New York: Scholastic.

\section{Expository}

Gibbons, G. (1996). Recycle:A handbook for kids. New York: Brown Young Readers.

Holub, J. (2003). Vilhy do horses neigh? New York: Puffin.

Prager, E. (2004). Volcano! Jump into science. Carmel, CA: National Geographic Children's Books.

Souza, D. (2007). Look what tails can do. Minneapolis: Lerner Publishing Group.

\section{Third grade}

Narrative

Clements, A. (1998). Frindle. New York, NY:Aladdin Paperbacks.

Dahl, R. (1988). Matilda. New York, NY:Viking.

McDonald, M. (2002). Judy Moody. New York, NY: Candlewick.

Woodruff, E. (1999). The memory coat. New York, NY: Scholastic.

Expository

Gibbons, G. (1998). Soaring with the wind:The bald eagle. New York, NY: Harper Collins.

Simon, S. ( 1993). Autumn across America. New York: Hyperion Books for Children.

Yoshida,T. (1989). Young lions. New York: Philomel. 
Finally, when we consider readers with ADHD we must take into account its high comorbidity with poor word reading skills (Willcutt \& Pennington, 2000). Thus, although poor attention is associated with weak inference and comprehension monitoring skills (e.g., Berthiaume, Lorch, \& Milich, 2010), this population may require an integrated intervention that includes both practice and support for decoding and higher level language comprehension skills.

\section{Conclusions}

Our review describes a strong evidence base that demonstrates higher level language skills - inferencing, comprehension monitoring, and text structure knowledge-are critical to good reading comprehension and its development. These higher level skills play an important role in a reader's (or listener's) construction of a representation of a text's meaning that is both accurate and coherent. We have shown how each of these skills can be assessed and supported in beginning readers, poor readers, and even prereaders by presenting information in visual (i.e., pictorial) or auditory (i.e., listening) formats, ensuring that the task is suitable for the developmental level of the child and that the material to be comprehended involves interesting topics. Further, there is increasing evidence that parents and educators can promote the development of these skills in everyday storybook reading and classroom discussions about texts. Clearly, skills beyond decoding make an important contribution to the determination of reading comprehension and can and should he supported during early language development.

It is important to note that our distinction between lower and higher level language skills is used primarily for descriptive purposes. Lower and higher level language skills do not operate in isolation. Take vocabulary as an example. A significant amount of vocabulary learning will occur in the context of literacy experiences even before children start school and begin reading instruction (e.g.. Sénéchal, Thomas, \& Monker, 1995). Vocabulary knowledge is certainly a prerequisite for understanding sentences and text. However, vocabulary is referred to as an unconstrained skill (Paris, 2005); during an individual's lifetime, vocabulary knowledge expands infinitely (Biemiller, 2005). Some of these gains will be the result of independent reading, because reading affords vocabulary learning opportunities (Cunningham \& Sta- novich, 1998) and higher level skills, such as inferring meaning from text, which appear crucial to vocabulary learning in adults (Daneman, 1988; Daneman \& Green, 1986). Indeed, vocabulary learning from text in children who are independent readers is related to their higher level reading comprehension skills (Cain, Oakhill, \& Lemmon, 2004), while children who are poor comprehenders do not make the same gains in vocabulary knowledge as good comprehenders between 7 and 11 years (Cain \& Oakhill, in press).Thus, vocabulary knowledge aids higher level comprehension skills (Perfetti, 2007), and these skills, in turn, aid vocabulary development. Grammar and reading comprehension are also reciprocally related. Readers use grammatical knowledge to comprehend text, while comprehending text increases knowledge of more complex syntactic structures often contained only in text (Nippold, 2007). Therefore, poorer comprehenders' morphemic knowledge develops at a slower rate than that of better comprehenders (Tong, Deacon, Kirby, Cain, \& Parilla, in press).

Few intervention studies have determined the best way to support and develop the higher level language skills in poor readers and prereaders, in contrast to the extensive work that has been published on phonological awareness and vocabulary development. We have identified how teachers (and parents) can include activities that foster these skills in daily routines involving shared storybook reading, but clearly this is a priority for future research in this field. Further, no studies have examined the efficacy of language-based comprehension instruction that includes the full complement of lower and higher level language skills crucial for developing reading comprehension. We consider this an essential next step, so that language instruction to support literacy development is both comprehensive and meets the needs of all developing readers: those who require support with decoding skills, those who require support with comprehension skills, and those who require support with both.

Acknowledgments - The creation of this manuscript was supported in part by the Institute of Education Sciences, U.S. Department of Education, through Grant R305F100002 to Ohio State University as part of the Reading for Understanding Research initiative. The opinions expressed are those of the authors and do not represent views of the Institute or the U.S. Department of Education. We thank Rachel Wiegert, Heidi Menard, Natalie Vanderveen, and Mimi Mann for assistance finding references, formatting the manuscript, and creating graphics, respectively. 


\section{References}

Aaron, P. G., Joshi. M., \& Williams, K. A. (1999). Not all reading disabilities are alike. Journal of Learning Disabilities, 32, 120-137.

Adlof, S. M., Catts, H. W., \& Little, T. D. (2006). Should the simple view of reading include a fluency component? Reading and Writing: An Interdisciplinary Journal, 19, 933-958.

Anderson, T. H., \& Armbruster, B. B. (1984). Content area textbooks. In R. C. Anderson, J. Osborne, \& R. J. Tierney (Eds.), Learning to read in American schools (pp. 193-226). Hillsdale, NJ: Erlbaum.

Applebee, A. N., Langer, J. A., Nystrand, M., \& Gamoran, A. (2003). Discussion-based approaches to developing understanding: Classroom instruction and student performance in middle and high school English. American Educational Research Journal, 40, 685-730.

Baker, L. (1984). Spontaneous versus instructed use of multiple standards for evaluating comprehension: Effects of age, reading proficiency, and type of standard. Journal of Experimental Child Psychology, 38, 289-311.

Baker, L., \& Zimlin, L. (1989). Instructional effects on children's use of two levels of standards for evaluating their comprehension. Journal of Educational Psychology, 81, 340-346.

Bakken, J. P., Mastropieri, M. A., \& Scruggs, T. E. (1997). Reading comprehension of expository science material and students with learning disabilities: A comparison of strategies. Journal of Special Education, 31, 300-324.

Barnes, M. A., Dennis, M., \& Haefele-Kalvaitis, J. (1996). The effects of knowledge availability and knowledge accessibility on coherence and elaborative inferencing in children from six to fifteen years of age. Journal of Experimental Child Psychology, 61, 216-241.

Baumann, J. F, Seifert-Kessell, N., \& Jones, L. A. (1992). Effect of think aloud instruction on elementary students' comprehension monitoring abilities. Journal of Reading Behavior, 26, 143-172.

Beck, I. L., \& McKeown, M. G. (2006). Improving comprehension with Questioning the Author: A fresh and expanded view of a powerful approach. New York: Scholastic.

Beck, I. L., McKeown, M. G., Sandora, C., Kucan, L., \& Worthy, J. (1996). Questioning the author: A yearlong classroom implementation to engage students with text. Elementary School Journal, 96(4), 385-414.

Beck, I. L., Omanson, R. C., \& McKeown, M. G. (1982). An instructional redesign of reading lessons: Effects on comprehension. Reading Research Quarterly, 17(4), 462-481.

Berthiaume, K. S., Lorch, E. P., \& Milich, R. (2010). Getting clued in: Inferential processing and comprehension monitoring in boys with ADHD. Journal of Attention Disorders, 14, 31-42.

Biemiller, A. (2005). Size and sequence in vocabulary development: Implications for choosing words for pri- mary grade vocabulary instruction. In A. Hiebert \& M. Kamil (Eds.), Teaching and learning vocabulary: Bringing research to practice (pp. 223-242). Mahwah, NJ: Erlbaum.

Bowyer-Crane, C., \& Snowling, J. (2005). Assessing children's inference generation: What do tests of reading comprehension measure? British Journal of Educational Psychology, 75, 189-201.

Bradshaw, M. L., Hoffman, P. R., \& Norris, J. A. (1998). Efficacy of expansions and cloze procedures in the development of interpretations by preschool children exhibiting delayed language development. Language, Speech, and Hearing Services in Schools, 29, 85-95.

Cain, K., \& Oakhill, J.V. (1999). Inference making ability and its relation to comprehension failure. Reading and Writing, 11, 489-503.

Cain, K., \& Oakhill, J. (2006). Assessment matters: Issues in the measurement of reading comprehension. British Journal of Educational Psychology, 76, 697-708.

Cain, K., \& Oakhill, J. V. (in press). Matthew effects in young readers: Reading comprehension and reading experience aid vocabulary development. Journal of Learning Disabilities.

Cain, K., Oakhill, J. V., Barnes, M. A., \& Bryant, P. E. (2001). Comprehension skill, inference-making ability, and the relation to knowledge. Memory E Cognition, 29, 850-859.

Cain, K., Oakhill, J., \& Bryant, P. (2004). Children's reading comprehension ability: Concurrent prediction by working memory, verbal ability, and component skills. Journal of Educational Psychology, 96, 31-42.

Cain, K., Oakhill, J., \& Lemmon, K. (2004). Individual differences in the inference of word meanings from context: The influence of reading comprehension, vocabulary knowledge, and memory capacity. Journal of Educational Psychology, 96, 671-681.

Carnine, D., \& Kinder, D. (1985). Teaching low-performing students to apply generative and schema strategies to narrative and expository material. Remedial and Special Education, 6, 20-27.

Caswell, L. J., \& Duke, N. K. (1998). Non-narrative as a catalyst tor literacy development. Language Arts, 75, 108-117.

Catts, H. W., Adlot, S. M., \& Ellis Weismer, S. E. (2006). Language deficits in poor comprehenders: A case for the simple view of reading. Journal of Speech, Language, and Hearing Research, 49, 278-293.

Catts, H. W., Fey, M. E., Tomblin, J. B., \& Zhang, X. (2002). A longitudinal investigation of reading outcomes in children with language impairments. Journal of Speech, language, and Hearing Research, 45, 1142-1157.

Catts, H. W., Fey, M. E., Zhang, X., \& Tomblin, J. B. (1999). Language basis of reading and reading disabilities: Evidence from a longitudinal investigation. Scientific Studies of Reading, 3, 331-361.

Catts, H. W., Hogan, T. P., \& Adlof, S. M. (2005). Developmental changes in reading and reading disabilities. In H. W. Catts \& A. G. Kamhi (Eds.), The connections be- 
tween language and reading disabilities (pp. 25-40). Mahwah, NJ: Erlbaum.

Catts, H. W., Hogan, T. P., \& Fey, M. E. (2003). Subgrouping poor readers on the basis of individual differences in reading related abilities. Journal of Learning Disabilities, 16, 151-164.

Chall, J. (1983). Stages of reading development. New York: McGraw-Hill.

Chapman, R. S. (1995). Language development in children and adolescents with Down syndrome. In P. Fletcher \& B. MacWhinney (Eds.), The handbook of child language (pp. 641-663). Oxford, UK: Blackwell.

Chapman, R. (2006). Language learning in Down syndrome: The speech and language profile compared with adolescents with cognitive impairment of unknown origin. Down Syndrome Research and Practice, 10, 61-66.

Chen, C.-Y. (2003). Guji Guji. La Jolla, CA: Kane/Miller.

Clarke, P. J., Snowling, M. J., Truelove, E., \& Hulme, C. (2010). Ameliorating children's reading-comprehension difficulties: A randomized controlled trial. Psychological Science, 21, 1106-1116.

Cunningham, A. E., \& Stanovich, K. E. (1998). What reading does for the mind. American Educator, 22, 8-15.

Daneman, M. (1988). Word knowledge and reading skill. In M. Daneman, G. MacKinnon, \& T. Waller (Eds.). Reading research: Advances in theory and practice (Vol. 6, pp. 145-175). San Diego, CA: Academic Press.

Daneman, M., \& Green, I. (1986). Individual differences in comprehending and producing words in context. Journal of Memory and Language, 25, 1-18.

de Jong, P. F., \& van der Leij, A. (2002). Effects of phonological abilities and linguistic comprehension on the development of reading. Scientific Studies of Reading, 6, 51-77.

de Sousa, I., \& Oakhill, J. V. (1996). Do levels of interest have an effect on children's comprehension monitoring importance? British Journal of Educational Psychology, 66, 471-482.

Denton, C. A., \& Mathes, P. G. (2003). Intervention tor struggling readers: Possibilities and challenges. In B. R. Foorman (Ed.), Preventing and remediating reading difficulties: Bringing science to scale (pp. 229-251). Timonium, MD: York Press.

Dickson, S. (1999). Integrating reading and writing to teach compare/contrast text structure: A research-based methodology. The Reading and Writing Quarterly, 15, 50.

Dimino, J. A., Taylor, R. M., \& Gersten, R. (1995). Synthesis of the research on story grammar as a means to increase comprehension. Reading and Writing Quarterly, $11,53-72$.

Doiron, R. (1994). Using nonfiction in a read-aloud program: Letting the facts speak for themselves. The Reading Teacher, 47, 616-624.

Duke, N. K. (2000). 3.6 minutes per day: The scarcity of informational texts in first grade. Reading Research Quarterly, 35, 202-224.
Duthie, C. (1994). Nonfiction: A genre study for the primary classroom. Language Arts, 71, 588-595.

Englert, C. S., \& Thomas, C. C. (1987). Sensitivity to text structure in reading and writing: A comparison between learning disabled and non-learning disabled students. Learning Disability Quarterly, 10, 93-105.

Gersten, R., Fuch, L. S., Williams, J. P., \& Baker, S. (2001). Teaching reading comprehension strategies to students with learning disabilities: A review of research. Review of Educational Research, 71, 279-320.

Gillam, S., Gillam, R., Petersen, D., \& Bingham, C. (2008). Narrative Language Intervention Program: Promoting oral language development. Technical session presented at the annual convention of the American Speech Language and Hearing Association, Chicago, IL.

Glaubman, R., Glaubman, H., \& Ofir, L. (1997). Effects of self-directed learning, story comprehension, and selfquestioning in kindergarten. The Journal of Educational Research, 90, 361-374.

Goldman, S. R., \& Rakestraw, J. A. (2000). Structural aspects of constructing meaning from text. In M. L. Kamil, P. B. Mosenthal, P. D. Pearson, \& R. Barr (Eds.). Handbook of reading research (Vol. 2. pp. 311-335). Mahwah, NJ: Erlbaum.

Gough, P. B., \& Tunmer, W. E. (1986). Decoding, reading and reading disability. Remedial and Special Education, 7, 6-10.

Graesser, A., \& Clark, L. (1985). Structures and procedures of implicit knowledge. Norwood, NJ: Ablex.

Hair, E., Halle, T., Terry-Humen, E., Lavelle, B., \& Calkins, J. (2006). Children's school readiness in the ECLS-K: Predictions to academic, health, and social outcomes in first grade. Early Childhood Research Quarterly, 21, 431-454.

Happé, F.. \& Frith, U. (2006). The weak coherence account: Detail-focused cognitive style in Autism Spectrum Disorders. Journal of Autism and Developmental Disorders, 36, 5-25.

Hogan, T. P., Bridges, M. S., Wymer, C., \& Volk, R. (2010). Tessa: A preschool child with a specific language impairment. In S. Chabon \& E. Cohn (Eds.). The communication disorders casebook: Learning by example (pp. 142156). Boston, MA: Allyn \& Bacon.

Hoover, W. A., \& Gough, P. B. (1990). The simple view of reading. Reading and Writing, 2, 127-160.

Justice, L. M., Bowles, R. P., \& Skibbe, L. E. (2006). Measuring preschool attainment of print-concept knowledge: A study of typical and at-risk 3- to 5-year-old children using item response theory. Language, Speech, and Hearing Services in Schools, 37, 224-235.

Justice, L. M., \& Ezell, H. K. (2002). Use of storybook reading to increase print awareness in at-risk children. American Journal of Speech-Language Pathology, 11, 17-29.

Justice, L. M., Mashburn, A., \& Petscher, Y. (in press). Very early language skills of fifth-grade poor comprehenders. Journal of Research in Reading. 
Kintsch, W., \& Kintsch, E. (2005). Comprehension. In S. G. Paris \& S. A. Stahl (Eds.), Current issues in reading comprehension and assessment (pp. 71-92). Mahwah, NJ: Erlbaum.

Langston, M. C., \& Trabasso, T. (1998). Modeling causal integration and availability of information during comprehension of narrative texts. In $\mathrm{H}$. van Oostendorp \& S. Goldman (Eds.), The construction of mental representation during reading (pp. 29-69). Mahwah, NJ: Erlbaum.

Lipson, M. Y. \& Wixson, K. K. (1986). Reading disability research: An interactionist perspective. Review of Educational Research, 56, 111-136.

Lynch, J. S., \& van den Broek, P. (2007). Understanding the glue of narrative structure: Children's on- and off-line inferences about characters' goals. Cognitive Development, 22, 323-340.

Mandler, J. M., \& Johnson, N. S. (1977). Remembrance of things parsed: Story structure and recall. Cognitive Psychology, 9, 111-151.

Markman, E. M. (1979). Realizing that you don't understand: Elementary school children's awareness of inconsistencies. Child Development, 50, 643-655.

Mayer, M. (1969). Frog, where are you? New York: Dial Books for Young Readers.

McKeown, M. G., Beck, I. L., \& Blake, R. G. K. (2009). Rethinking reading comprehension instruction: A comparison of instruction for strategies and content approaches. Reading Research Quarterly, 44, 218-253.

Moss, B. (2004). Teaching expository text structures through information. The Reading Teacher, 57, 710-718.

Nation, K. (1999). Reading skills in hyperlexia: A developmental perspective. Psychological Bulletin, 125, 338-355.

Nation, K. (2005). Why reading comprehension fails: Insights from developmental disorders. Topics in Language Disorders, 25, 21-32.

Nation, K., Clarke, P., Marshall, C. M., \& Durand, M. (2004). Hidden language impairments in children: Parallels between poor reading comprehension and specific language impairment. Journal of Speech, Language, and Hearing Research, 47, 199-211.

Nippold, M. (2007). Later language development: School-age children, adolescents, and young adults (3rd ed.). Austin, TX: Pro-Ed.

Norbury, C. F., \& Bishop, D. V. M. (2002). Inferential processing and story recall in children with communication problems: a comparison of specific language impairment, pragmatic language impairment, and high-functioning autism. International Journal of Language and Communication Disorders, 37, 227-251.

Oakhill, J., \& Cain, K. (in press). The precursors of reading comprehension and word reading in young readers: Evidence from a four-year longitudinal study. Scientific Studies of Reading.

Palmer, R. G., \& Stewart, R. A. (2003). Nonfiction trade book use in primary grades. The Reading Teacher, 57, 3848 .
Pappas, C. C. (1993). Is narrative "primary"? Some insights from kindergarteners' pretend readings of stories and information books. Journal of Literacy Research, 25, 97-129.

Paris, S. G. (2005). Reinterpreting the development of reading skills. Reading Research Quarterly, 40, 184-202.

Paris, S. G., \& Jacobs, J. E. (1984). The benefits of informed instruction for children's reading awareness and comprehension skills. Child Development, 55, 2083-2093.

Pearson, P. D. (1982). Asking questions about stories. Ginn occasional papers (No. 15). Columbus, OH: Ginn.

Penno, J. F., Wilkinson, I. A. G., \& Moore, D. W. (2002). Vocabulary acquisition from teacher explanation and repeated listening to stories: Do they overcome the Matthew effect? Journal of Educational Psychology, 94(1), 23-33.

Perfetti, C. A. (2007). Reading ability: Lexical quality to comprehension. Scientific Studies of Reading, 11, 357-383.

Perfetti, C. A. (2009, June). Reducing the complexities of reading comprehension: A simplifying framework. Paper presented at the Institute of Education Sciences Research Conference. Washington, DC.

Perfetti, C. A., Landi, N., \& Oakhill, J. (2005). The acquisition of reading comprehension skill, In M. J. Snowling \& C. Hulme (Eds.), The Science of reading: A handbook (pp. 227-247). Maiden, MA: Blackwell.

Pressley, M., \& Afflerbach, P. (1995). Verbal protocols of reading: The nature of constructively responsive reading. Hillsdale, NJ: Erlbaum.

Roch, M., Florit, E., \& Levorato, M. C. (2011). Follow-up study on reading comprehension in Down's syndrome: The role of reading skills and listening comprehension. International Journal of Communication Disorders, 46, 231-242.

Roch, M., \& Levorato, M. C. (2009). Simple View of Reading in Down's syndrome: The role of listening comprehension and reading skills. International Journal of Communication Disorders, 44, 206-223.

Saul, E. W., \& Dieckman, D. (2005). Choosing and using information trade books. Reading Research Quarterly, 40, 502-513.

Sénéchal, M., Thomas, E., \& Monker, J.-A. (1995). Individual differences in 4-year-old children's acquisition of vocabulary during storybook reading. Journal of Educational Psychology, 87, 218-229.

Simmons, D. C., Coyne, M. D., Kwok, O., McDonagh, S., Harn, B. A., \& Kame'enui, E. J. (2008). Indexing response to intervention: A longitudinal study of reading risk from kindergarten through third grade. Journal of Learning Disabilities, 41(2), 158-173.

Singer, M. H., \& Crouse, J. (1981). The relationship of context-use skills to reading: A case for an alternative experimental logic. Child Development, 52, 1326-1329.

Skarakis-Doyle, E. (2002). Young children's detection of violations in familiar stories and emerging comprehension monitoring. Discourse Processes, 33, 175-197. 
Stein, N. L., \& Trabasso, T. (1982). What's in a story: An approach to comprehension and instruction. In R. Glaser (Ed.). Advances in instructional psychology (Vol. 2. pp. 213-267). Hillsdale, NJ: Erlbaum.

Stuebing, K. E., Barth, A. E., Molfese, P. J., Weiss, B., \& Fletcher, J. M. (2009). IQ is not strongly related to response to reading instruction: A meta-analytic interpretation. Exceptional Children, 76, 31-51.

Tong, X., Deacon, S. H., Kirby, J. R., Cain, K., \& Parilla, R. (in press). Morphological awareness: A key to understanding poor reading comprehension in English. Journal of Educational Psychology.

Torgesen, J., \& Davis, C. (1996). Individual difference variables that predict response to training in phonological awareness. Journal of Experimental Child Psychology, 63, $1-21$.

van den Brock, P. W. (1997). Discovering the cement of the universe: The development of event comprehension from childhood to adulthood. In P. W. van den Broek, P. J. Bauer, \& T. Bourg (Eds.), Developmental spans in event comprehension and representation (pp. 321-342). Mahwah, NJ: Erlbaum.

van Kleeck, A. (2008). Providing preschool foundations for later reading comprehension: The importance of and ideas for targeting inferencing in story-book sharing interventions. Psychology in the Schools, 45, 627-643.

van Kleeck, A., Vander Woude, J., \& Hammett, L. (2006). Fostering literal and inferential language skills in Head Start preschoolers with language impairment using scripted book-sharing discussions. American Journal of Speech-Language Pathology, 15, 85-95.

Vellutino, F R., Scanlon, D. M., Small, S., \& Fanuele, D. P. (2006). Response to intervention as a vehicle for distinguishing between children with and without reading disabilities: Evidence for the role of kindergarten and first-grade interventions. Journal of Learning Disabilities, $39,157-169$.

Westerveld, M. F., \& Gillon, G. T. (2008). Oral narrative intervention for children with mixed reading disability. Child Language Teaching and Therapy. 24(1). 31-54. doi: 10.1177/0265659007084567

Whitehurst, G. J., Falco, F. L., Lonigan, C. J., \& Fischel, J. E. (1988). Accelerating language development through picture book reading. Developmental Psychology, 24, $552-559$.
Whitehurst, G. J., \& Lonigan, C. J. (1998). Child development and emergent literacy. Child Development, 69, 848-872.

Willcutt, E., \& Pennington, B. F. (2000). Comorbidity of reading disability and attention-deficit/hyperactivity disorder. Journal of Learning Disabilities, 33, 179-191.

Williams, D. L., Goldstein, G., \& Minshew, N. J. (2005). Impaired memory for faces and social scenes in autism: Clinical implications of memory dysfunction. Archives of Clinical Neuropsychology, 20, 1-15.

Williams, J. P., Nubla-Kung, A. M., Pollini, S., Stafford, K. B., Garcia, A., \& Snyder, A. E. (2007). Teaching cause-effect text structure through social studies contents to atrisk second graders. Journal of Learning Disabilities, 40, 111-120.

Williams, J. P., Stafford, K. B., Lauer, K. D., Hall, K. M., \& Pollini, S. (2009). Embedding reading comprehension training in content area instruction. Journal of Educational Psychology, 101, 1-20.

Yuill, N., \& Oakhill, J. (1988). Understanding of anaphoric relations in skilled and less skilled comprehenders. British Journal of Psychology, 79, 173-186.

Yuill, N., \& Oakhill, J. (1991). Children's problems in text comprehension: An experimental investigation. New York: Cambridge University Press.

Zevenbergen, A. A., Whitehurst, G. J., \& Zevenbergen, J. A. (2003). Effects of a shared-reading intervention on the inclusion of evaluative devices in narratives of children from low-income families. Journal of Applied Developmental Psychology, 24, 1-15.

Zipke, M., Ehri, L. E., \& Cairns, H. (2009). Using semantic ambiguity instruction to improve third graders' metalinguistic awareness and reading comprehension: An experimental study. Reading Research Quarterly, 440, 300-321.

Zucker, T. A., Justice, L. M., Piasta, S. B., \& Kaderavek, J. N. (2010). Preschool teachers' literal and inferential questions and children's responses during whole-class shared reading. Early Childhood Research Quarterly, 25, 65-83. 